\title{
La perfecta privanza según Francisco de Quevedo: de la aproximación teórica a la visión dramatizada
}

\author{
Marta Piłat-Zuzankiewicz \\ Universidad de Varsovia \\ Instytut Studiów Iberyjskich i Iberoamerykanskich \\ Uniwersytetu Warszawskiego \\ ul. Obozna 8 \\ 00-927 Warszawa \\ Polonia \\ marta_pilat@yahoo.es
}

[La Perinola, (Issn: 1138-6363), 21, 2017, pp. 67-97]

DOI: $10.15581 / 017.21 .67-97$

Francisco de Quevedo es testigo de unos profundos cambios que se producen en la monarquía personal española a causa de la aparición al frente del aparato de la administración de la figura del privado, consejero especial que apoya al rey en el ejercicio de las tareas de gobierno. Comprometido desde el principio de su carrera cortesana con la vida política de su tiempo, el autor toma una parte activa en el debate que este fenómeno suscita entre los tratadistas políticos de aquel entonces. En el contexto de la polémica sobre la pertinencia de la privanza cabe destacar tres obras quevedianas que constituyen una aportación valiosa al respecto: el Discurso de las privanzas, escrito bajo el gobierno de Lerma, la Política de Dios, acabada en el momento del cambio de régimen, y la comedia Cómo ha de ser el privado, compuesta por encargo de Olivares, en la cual don Francisco lleva a la escena su teoría política. Dada la complejidad de los mencionados textos, que da pie a interpretaciones varias veces contradictorias de la actitud del autor hacia la figura del valido, en el presente artículo proponemos adoptar un enfoque histórico-político, que permita profundizar en las circunstancias de la composición de las piezas analizadas así como situarlas dentro de una larga tradición de discusión teórica sobre el sistema de gobierno en España.

\section{LA CUESTIÓN DE LA PRIVANZA EN LA TRATADÍSTICA ESPAÑOLA}

El debate sobre la privanza en España se remonta al siglo xv y surge a raíz de la crítica del gobierno de Álvaro de Luna. Uno de los primeros 
en participar en ella es el marqués de Santillana, quien en su Doctrinal de privados (1453) acusa al favorito de Juan II de Castilla de haber abusado de la confianza del monarca y acaparado un poder que no le correspondía. Los recuerdos de la guerra civil, que provocó el enfrentamiento de Luna con los infantes de Aragón y los grandes de Castilla, hacen que la valoración negativa de la privanza perdure también en la época de los Reyes Católicos. Lo corrobora un texto anónimo de 1493 que contiene avisos contra los perversos consejeros que se hacen dueños de la voluntad del monarca para acumular riquezas y poder ${ }^{1}$.

Unas opiniones menos unánimes se presentan a partir de la primera mitad de la centuria siguiente como resultado de los cambios que introducen en el aparato administrativo español los reyes de la Casa de Austria. Es por aquel entonces cuando los secretarios reales, a los que los contemporáneos no dudan en calificar como privados ${ }^{2}$, empiezan a desempeñar un papel principal en el Consejo de Estado. Estos colaboradores de Carlos V y Felipe II gozan de la confianza y amistad de sus respectivos señores $y$, de acuerdo con la etiqueta borgoñona ${ }^{3}$, son los únicos que disfrutan del favor de despachar con ellos a boca. Dada la existencia de los validos en la corte del emperador, fray Antonio de Guevara en su Aviso de privados (1539), dedicado a uno de ellos, don Francisco de los Cobos, no indaga sobre la conveniencia de la privanza, sino que ofrece a sus lectores una serie de consejos prácticos para conquistar, ejercer bien y conservarla. En cambio, Pedro Mexía, al adoptar en la Silva de varia lección (1540) una óptica tradicionalista, vincula la privanza con la debilidad e inclinación al vicio del rey y su favorito, resaltando la codicia de bienes y honras de este último.

La experiencia política de Felipe II y sus ministros permite a finales del siglo xvi forjar una teoría positiva sobre la figura del privado. La desarrolla Marco Antonio Camos, quien apunta en su Microcosmía y gobierno universal del hombre (1592) a la utilidad de un hombre de confianza que ayude al monarca a manejar los asuntos de Estado y le proteja de las quejas del pueblo. En términos similares se pronuncia Antonio Pérez en su carta dirigida a Lerma (1594) haciendo hincapié en que la valoración de la privanza depende en gran medida de las cualidades morales de los individuos que la ejercen. En el lado opuesto se sitúan los defensores del sistema polisinodial como Luis Manrique o Luis de Padilla que, aspirando a restaurar el poder de los consejos en detrimento del de los validos, critican en sus panfletos y memoriales el estilo de gobierno de Felipe II y animan a su heredero a revocar sus reformas ${ }^{4}$.

1. Ver Feros, 2002, p. 94.

2. Para más información sobre los privados de Carlos V y Felipe II ver Escudero, 2010, pp. 322-323; Elliott, 1997, pp. 888-991; Feros, 2002, pp. 68-74.

3. El ceremonial borgoñón, impuesto por Carlos V en 1548, garantizaba la privacidad y distancia del monarca, al que tenía acceso solo un número reducido de servidores. Ver Feros, 2002, 162-167; Elliott, 1997, p. 892.

4. Ver Feros, 2002, pp. 113-118. 
En el período de juventud de Felipe III se incrementa el número de las críticas contra la privanza, que aprovechan la argumentación proporcionada por los teóricos políticos extranjeros como Nicolás Maquiavelo o Justo Lipsio. Estos, aunque admiten la necesidad de que al príncipe no le falten consejeros, perciben como un peligro para su autoridad el hecho de favorecer a solo uno de ellos. Sus opiniones las comparten los antimaquiavelistas españoles como Pedro de Rivadaneyra (Tratado de la religión y virtudes que debe tener el príncipe cristiano, 1595) y Juan de Mariana (De rege et regis institutione 1599). Por otra parte, bajo el patrocinio del duque de Lerma se produce un intento de legitimar el poder del valido y justificar su papel en el gobierno de la monarquía. Los partidarios del favorito real, Álamos de Barrientos en el Norte de príncipes (1599 / 1600) y Fernández de Medrano en la República mixta (1602), abogan por la provechosa unidad en la cima del gobierno, entendida como la relación de un rey con solo un privado, quien asume responsabilidades diferentes a las de los demás consejeros. Una valiosa aportación a este proyecto la hace el confesor de Lerma, fray Pedro Maldonado, presentando en el Discurso del perfecto privado $\left(1609^{5}\right)$ una novedosa definición del privado:

un hombre con quien (el rey) a solas y particularmente se comunica, con quien hay cosa secreta, escogido entre los demás para una cierta manera de igualdad, fundada en amor y perfecta amistad ${ }^{6}$.

El argumento de la amistad entre el rey y uno de sus vasallos, fundada en la supuesta igualdad entre ambos, lo refuta en su Tratado de la república y política christiana (1615) fray Juan de Santamaría. En su obra el franciscano señala como dignos de imitar los ejemplos bíblicos de la privanza y se pronuncia a favor de que el soberano posea varios validos.

La convicción de la conveniencia de la institución del valimiento sigue viva también en el momento del cambio de gobierno de 1621 . Prueba de ello son las advertencias de fray Gerónimo de Florencia, dirigidas al joven Felipe IV, sobre la necesidad de tener a su lado a un sirviente especial, a quien correspondería estar a cargo de todos los negocios públicos?. Como señala Antonio Feros, el discurso legitimizador del poder del valido de Felipe IV no difiere radicalmente de la argumentación usada a favor de Lerma ${ }^{8}$. La idea de amor y una especial amistad que unen al monarca y su favorito se repite en dos tratados dedicados al conde-duque: el Perfecto privado (1622) de Matheo Renzi y el Privado cristiano de José Lainez (1641), siendo este último un plagio de la obra del padre Maldonado9. Juan Pablo Mártir Rizo en el Norte

5. Durand, 1980, p. 315, sitúa la composición de la obra hacia 1603.

6. Maldonado, Discurso del perfecto privado, p. 1.

7. Ver Feros, 2000, p. 304.

8. Ver Feros, 2000, pp. 304-305.

9. Ver Tomás y Valiente, 1982, p. 125. 
de príncipes (1626) y Pedro Martínez de Herrera en El príncipe advertido (1631) admiten la doble naturaleza pública y privada del privado, ministro y amigo del rey, destacando las ventajas políticas que aporta para el Estado el hecho de que alguien le ayude al monarca a llevar el peso de la república. Diego de Saavedra Fajardo comparte estos argumentos en su Idea de un príncipe político y cristiano (1640), aunque llama la atención de la necesidad de que el soberano ponga ciertos límites a su valido, de modo que su relación se entienda como una división del trabajo y no un reparto del poder.

En comparación con las aportaciones de sus contemporáneos, la concepción de la privanza que presenta Francisco de Quevedo no es ni original ni sistemática, sino más bien un resultado del re-pensamiento ${ }^{10}$ de las ideas de otros teóricos del arte de gobierno. En las páginas que siguen efectuamos un detallado análisis de sus obras escritas en las primeras tres décadas del siglo xvII, enfocándonos en la similitud que guardan con los importantes textos tratadísticos de su tiempo. Tratamos de identificar los conceptos retomados y desarrollados por el autor en su teoría del perfecto sistema de gobierno, así como presentar una cierta evolución de su pensamiento político.

\section{Discurso DE LAS PRIVANZAS: UN INTENTO DE LEgItimar el VALIMIENTO DE Lerma}

La intención que guía a Quevedo a escribir y dedicar a Felipe III el Discurso de las privanzas entre 1606 y $1608^{11}$ ha sido hasta ahora objeto de pocos estudios. Santiago Fernández Mosquera considera como lo más probable la intención de buscar reconocimiento en la corte y posibilidades de participar en la vida política de aquel entonces. Al mismo tiempo el investigador señala la poco acertada decisión de componer un tratado sobre el privado en un momento en que el valimiento de Lerma está en una fase de pleno desarrollo y la incómoda situación en que se halla el mismo autor porque «si aconseja sobre una elección ya hecha, tendría que coincidir con el elegido; si no coincide, disiente del rey por su elección y de la persona elegida, el propio valido» ${ }^{12}$. Para Elise Monjarret, la obra constituye una muestra del uso virtuoso de la técnica cortesana de criticar por medio de la adulación. La estudiosa la califica como un panfleto que le sirve a Quevedo para denunciar, con los aparentes elogios del duque de Lerma, los males de su gobierno y, de esta manera, dar a conocer su inicial y radical desconfianza respecto al fenomeno de la privanza ${ }^{13}$.

10. Ver Aranguren, 1950, p. 157.

11. Ver Díaz Martínez, 2000, p. 57-58.

12. Fernández Mosquera, 2013, p. 556.

13. Ver Monjarret, 2010. 
Por el contrario, Fernando Rubio ${ }^{14}$ y Victoriano Roncero, fijándose en la fecha de composición del texto, próxima a la de otros tratados de la privanza amparados por Lerma, coinciden en que su objetivo no es otro que el de exaltar al favorito de Felipe III. Roncero apoya su tesis con los datos sobre la relación que Quevedo mantuvo en esta época con la familia del duque y la ayuda que recibió de su esposa, doña Catalina de la Cerda, cuando tenía problemas con la justicia por haber participado en un duelo ${ }^{15}$. Además, teniendo en cuenta la situación personal del autor, pues «no era por entonces más que un escritorcillo entre gigantes» ${ }^{16}$, y las medidas de presión tomadas por Lerma contra los que intentaran criticar o amenazar su privanza ${ }^{17}$, nos parece poco probable que don Francisco dedicara su primera obra política seria a censurar el gobierno del valido, de quien dependía su futuro en la corte.

El posible involucramiento de Quevedo en la campaña de legitimación de la privanza de Lerma permite explicar el porqué de la selección de temas planteados en su obra. A primera vista el Discurso de las privanzas parece un tratado teórico y general, cuyo autor pretende lucir su conocimiento político y filosófico por apelar a los ideales neoestoicos, presentar ejemplos históricos sacados de Plutarco y Tácito y refutar las teorías de Maquiavelo. No obstante, como señala Fernández Mosquera, tal clasificación de la obra queda desmentida por la estrategia narrativa adoptada por don Francisco, las apelaciones directas al rey Felipe III y los elogios del gobierno de Lerma ${ }^{18}$. Parece que originariamente el discurso surge como un esbozo de carácter teórico y más tarde sufre una remodelación enriqueciéndose con alusiones a la situación política actual. El texto se compone de diez capítulos, de los cuales los primeros cinco abordan los temas típicos de este género de tratados: la necesidad de la existencia del privado; su papel y la relación con el rey; las mudanzas de la fortuna que pueden afectar a la privanza y las cualidades del privado perfecto. La segunda mitad del discurso gira en torno al tema de la conservación de la privanza e incluye una serie de consejos prácticos sobre cómo diferenciar entre amigos y aduladores, qué comportamiento adoptar frente a los enemigos públicos y secretos, qué medidas tomar para asegurarse de ellos, castigar o ganar su simpatía y, finalmente, cómo un privado odiado ha de reconquistar el amor de su señor y del reino.

La decisión de dedicar los últimos cinco capítulos de la obra, destinada al rey, a la cuestión de preservar el poder del privado parece sorprendente, ya que más convendría ofrecérselos al duque de Lerma,

14. Ver Rubio, 1964, pp. 581-582.

15. Ver Roncero, 2013, p. 76. Gracias a la intervención de la protectora de la madre del autor, este fue condenado a una prisión atenuada, de la que quedaría libre en 1605. Ver Linde, 2005, p. 44.

16. Jauralde, 1998, p. 179.

17. Ver Feros, 2002, p. 309.

18. Ver Fernández Mosquera, 2013, p. 556. 
quien podría sacar de ellos algún provecho. No obstante, tal procedimiento resulta completamente comprensible si tenemos en cuenta el contexto histórico-político de la composición del discurso, el cual puede arrojar una nueva luz sobre la verdadera motivación de Quevedo. Cabe recordar que a partir de 1605 en la corte se incrementaron las acusaciones de corrupción contra los protegidos del privado: Pedro Franqueza y Esteve, Alonso Ramírez de Prado y Rodrigo Calderón. Su detención y procesamiento, que tuvieron lugar dos años más tarde, provocaron una grave crisis de confianza política. Los enemigos de Lerma aprovecharon esta ocasión no solo para censurar las escandalosas prácticas de sus favoritos, sino también para cuestionar el régimen de privanza, la existencia de un solo valido y de una única facción cortesana que poseía el monopolio del favor real y, sintiéndose intocable, se atrevía a cometer abusos. Dichas críticas se intensificaron en junio de 1608, cuando en las puertas del palacio real y de la cárcel real aparecieron pasquines que denunciaban la privanza tiránica de Lerma y pedían al rey remediar la situación. Para salvar su posición el duque adoptó unas medidas radicales: por una parte, puso en prueba su amistad con Felipe III declarando la intención de retirarse de la vida pública, para lo cual no obtuvo finalmente la licencia real, por otra, puso en marcha una campaña de propaganda en defensa de su gobierno ${ }^{19}$.

En vista de lo expuesto adquieren un nuevo sentido las palabras finales de la obra, con las cuales don Francisco alaba a Lerma y sus colaboradores, resaltando que estos son igual de buenos y entregados al servicio del rey que su protector:

Dé v.M. gracias a Dios de que le ha dado un criado tal como el Duque, que no le ha dado lugar que tenga nombre lo que le ha dado más de merced que de paga y premio. Tanto y tan bien ha servido y sirve, que merece muy bien que sean semejantes suyos los que le ayudan a llevar la carga que sólo en sus hombros descansa ${ }^{20}$.

Tampoco resulta fortuito, a nuestro juicio, que en el mismo capítulo, titulado «De qué usará el privado que hubiere adquerido odio para ser amado, y cómo enderezará su privanza», Quevedo proponga como modelo a seguir para el valido, que quiere recobrar la confianza perdida de su señor, el comportamiento de Séneca, quien para acabar con las murmuraciones sobre su riqueza devuelve a Nerón todos los obsequios de él recibidos. Además de esta clara alusión a las críticas de la insaciable ansia de enriquecerse de Lerma, don Francisco hace en su texto otra, relativa a la posible retirada del duque de la corte, cuando recomienda al privado caído en desgracia abandonar el vicio y volver al camino de la virtud asegurando que de esta manera adquirirá una doblada afición

19. Ver Feros, 2002, pp. 312-335.

20. Quevedo, Discurso de las privanzas, p. 249. 
de su señor ya que «entre los sanctos, los mayores han sido los que fueron más apartados en algún tiempo» ${ }^{21}$.

No menos significativa parece ser la primera apelación que el autor dirige a Felipe III a finales del capítulo segundo, en el que identifica la voluntad del monarca con la rueda de la fortuna que puede subir y bajar al privado por un capricho o error del señor engañado por otros. Planteando el caso hipotético del apartamiento del buen privado, cuyas altas cualidades descritas en la obra se personifican en la figura del duque de Lerma ${ }^{22}$, Quevedo aconseja a Felipe III no deponerlo de su cargo demostrando que tal acción no solo le deshonraría al favorito, sino que también pondría en tela de juicio la rectitud de la elección realizada por el mismo rey:

Mejor le está a v.m. la estabilidad del privado virtuoso que al mismo, porque al principio acredita su persona sola, y en conservarle acredita su persona y la eletión que tuvo tan acertada en escogerle para bien de tantos sin agraviar a ninguno ${ }^{23}$.

De igual manera don Francisco se pronuncia a favor de la elección de Lerma en el capítulo tercero de su discurso, donde expone que el privado debería ser rico y poderoso. Resalta los beneficios que aporta tener como valido un miembro de la grandeza al alabar las virtudes morales con que el descendiente de un linaje noble supera al servidor pobre. Avisa del peligro que supone para el pueblo un favorito deseoso de salir de su pobreza a toda costa y la dependiencia del letrado de los que le han hecho subir. Pero el argumento de mayor importancia que presenta es el que el hombre poderoso tenga parientes a quienes se ha de premiar con puestos para reforzar de esta manera la autoridad de sus oficios. Llegado a este punto, el autor no duda en destacar el acierto con que Lerma llegó a repartir los altos cargos administrativos entre sus familiares:

Guarde Dios a v.M. mil años, y al Duque en su servicio por el consejo que le ha dado de que honre los oficios con las personas a quien los ha dado, poniendo tantos grandes así en su servicio como en el de la república, cosa que al pueblo ha doblado la obediencia de sus leyes y pragmáticas. Importa mucho, señor, un Conde de Miranda y un Conde de Lemos, otros grandes señores así en Consejos donde se trata de justicia ${ }^{24}$.

Esta alabanza del clientelismo, nada frecuente en los posteriores textos quevedianos, se debe al apoyo del escritor a un cambio que en aquel momento considera imprescindible para el gobierno de la monarquía española. Este tiene por objetivo el fortalecimento del poder

21. Quevedo, Discurso de las privanzas, p. 248.

22. Ver Roncero, 2013, pp. 79-82.

23. Quevedo, Discurso de las privanzas, p. 201.

24. Quevedo, Discurso de las privanzas, p. 208. 
real frente a la rígida máquina administrativa, para lo cual se requiere la creación de redes de lealtad personal, control del patronazgo y distribución de mercedes que promuevan el servicio a la corona ${ }^{25}$. La consciencia de que el faccionalismo amenaza con subvertir el sistema de gobierno personalista puede ser la razón de la valoración positiva que hace Quevedo del papel del privado y sus prerrogativas ${ }^{26}$ de colocar «en los puestos que son para eso (aconsejando al rey que lo haga) hombres beneméritos por virtud y letras del cargo, advirtiendo las faltas de todos, éstas para castigarlas y los servicios para premiarlos $)^{27}$.

Otras alusiones al gobierno de Lerma se hallan en el capítulo octavo de la obra, que trata de cómo el privado debe protegerse de los grandes y ganar la voluntad del pueblo. Los pasajes dedicados a las consecuencias de la envidia cortesana no ofrecen detalles sobre las luchas de facciones en que toma parte el duque, pero entre los consejos sobre el tratamiento del pueblo detectamos dos que remiten a su práctica política. Con una de las advertencias don Francisco pretende justificar el enriquecimiento del privado haciendo una distinción entre el vicio de tomar y la obligacion del rey de recompensar los servicios de su favorito de modo que «no lo atribuya nadie a cudicia y negociación antes que a premio y mérito suyo ${ }^{28}$. Otra recomendación quevediana se refiere al deber del privado de facilitar a los súbditos acceso al monarca y dar audiencias públicas a los que lo necesiten. El mismo autor asegura que Lerma cumple perfectamente con dicha tarea no solo al atender a todos sino también al salir a buscar a los negociantes. Y termina este pasaje con una observación que Díaz Martínez interpreta como una referencia a la suspensión de audiencias del favorito real por las depresiones y melancolías que sufría a partir de $1605^{29}$ : «Pluguiera a Dios que como lo ha hecho agora lo hubiera hecho siempre; el hacerlo le estaba bien sobre todas las cosas del mundo para ganar corazones» ${ }^{30}$.

El ingenioso plan quevediano de la defensa de Lerma contra sus detractores consiste en insertar valoraciones positivas de su gobierno en un texto de carácter universal, pensado no solo como un manual sobre el perfecto privado, digno de ser imitado por los colaboradores reales, sino también como un escrito que legitime el régimen de privanza. La teoría en él expuesta carece de mucha originalidad y reúne motivos y temas abordados en los tratados compuestos por los mismos años o con poca diferencia de tiempo. La definición quevediana de la privanza como “un amor o afición entre muchos sujetos a uno»" completada más adelante con la representación del valido como un buen amigo del

25. Ver Elliott, 1997, p. 894.

26. Ver Roncero, 2013, p. 80.

27. Quevedo, Discurso de las privanzas, pp. 212-213.

28. Quevedo, Discurso de las privanzas, p. 238.

29. Quevedo, Discurso de las privanzas, p. 238, nota 152.

30. Quevedo, Discurso de las privanzas, p. 238.

31. Quevedo, Discurso de las privanzas, p. 197. 
rey que «es muchas veces de gusto y todas es de provecho» ${ }^{32}$, refleja los elementos esenciales de la concepción del padre Maldonado ${ }^{33}$. La imagen modélica del privado elaborada por don Francisco se funda en la idea senequiana de vir sapiens, un sabio estoico, virtuoso y prudente, que no deja llevarse por las pasiones ni por la ambición de gobernar. Al proponer el alto ideal moral basado en la virtud que, de acuerdo con la doctrina estoica, protege al favorito real de las inconstancias de la fortuna también coincide Quevedo con los avisos del confesor de Lerma ${ }^{34}$. $\mathrm{Y}$ al identificar el ciego destino con la clibre aunque inclinada voluntad del príncipe sujeta a mudanzas $)^{35}$, responsable del ascenso y caída, conquista y pérdida del favor y confianza real, retoma el motivo que se vuelve constante en los espejos de privados a partir de la publicación del tratado de fray Antonio de Guevara ${ }^{36}$.

Una interesante desviación de la línea representada por los moralistas políticos la realiza Quevedo al aplicar un criterio pragmático a la hora de hacer una división entre los dos géneros principales de privanzas: las perecederas y las duraderas, y al definir las últimas como las «que obedecen a la inclinación natural, a la virtud o el vicio» ${ }^{37}$. A continuación, el autor pretende suavizar la aparente equiparación de la virtud y el vicio, que no vuelve a repertirse en otras obras suyas, asegurando que al acompañar al monarca virtuoso el mal valido cen el ejemplo virtuoso y prudente es forzado a imitar(le), cuando no con la voluntad, con el tiempo y con la costumbres ${ }^{38}$. Tal afirmación difiere de la observación del confesor de Lerma, quien sostiene que es más segura la república con un rey malo y privados buenos que al revés, ya que «es más fácil que el privado malo haga malo al rey que al revés que el rey bueno haga bueno al privado »39. Además, el mismo Quevedo se contradice atribuyendo primero al rey la tarea de reformar los hábitos de su valido para, más adelante, insistir en que este, como dueño de la voluntad del príncipe, ha de enderezar a su señor «encaminandole siempre a la virtud y apartándole de todos los que le pueden apartar della» ${ }^{40}$. En este último punto el autor concuerda con la opinión de

32. Quevedo, Discurso de las privanzas, pp. 221-222.

33. Fernando Rubio es el primero que indica varias coincidencias entre entre el Discurso de las privanzas de Quevedo y el Discurso del perfecto privado del padre Maldonado. Ver Rubio, 1964.

34. Maldonado, Discurso del perfecto privado, p. 33: «No hay cosa que así gana crédito y autoridad con los hombres como el concepto y crédito de su virtud; tienenle por hombre regido de Dios, guardado de fuerzas superiores, no sujeto a fueros de fortuna».

35. Quevedo, Discurso de las privanzas, p. 215.

36. Ver Guevara, Libro llamado Aviso de privados, pp. 103-104.

37. Quevedo, Discurso de las privanzas, p. 197.

38. Quevedo, Discurso de las privanzas, pp. 197-198.

39. Maldonado, Discurso del perfecto privado, p. 7.

40. Quevedo, Discurso de las privanzas, p. 211. 
Maldonado, quien atribuye al privado la misión de enseñarle al rey a vencer los afectos le que desdoran ${ }^{41}$.

Don Francisco coincide con el religioso al abogar por el sistema de privanza, refutar los argumentos utilizados por los oponentes de tal régimen y defender la existencia de un único privado porque «natural es en todos los hombres inclinarse más a uno que a otro, como se ve en todas las ocasiones que un hombre ve hacer a otros muchos arrimándose a uno siempre ${ }^{42}$. Entre los inconvenientes de no tener un solo valido el autor indica los problemas que genera la necesidad de dar igual confianza a todos los colaboradores, tomar decisión sin saber cuyo consejo aceptar, dar licencia a solicitudes de varios ambiciosos de la privanza y la obligación de hablar con cada uno en particular o con ninguno. Para terminar apunta a la conveniencia de que el rey comparta el peso del gobierno con un hombre de confianza que no le sustituya sino que le haga descansar a ratos, concepto que presenta recurriendo a una sugestiva imagen de Alcides ayudando a Atlante a sustentar el firmamento.

Al mismo tiempo Quevedo hace hincapié en la desigualdad de rango social entre el monarca y su colaborador "porque dos señores en nada hallan paz» ${ }^{43}$. Esta observación también la ilustra con una figura simbólica, utilizada antes por Lipsio ${ }^{44}$, del príncipe-sol y el ministroluna, que debe esconderse de aquél para no competir con él en luz y causente dél, ha de suplir como pudiere su falta» ${ }^{45}$. De esta manera, don Francisco reduce la función del privado a la de un simple ayudante del rey que le alivia el trabajo, pero en ningún momento usurpa sus funciones. También le aconseja no guardar mucha familiaridad con su señor, aunque el mismo por amor le dé ocasión para eso, sino mostrarle respeto y reverencia y dejar ver al rey «entre toda esa amistad la obediencia arrimada a la estima del favor ${ }^{46}$. Recuerda al valido que, aunque es dueño de la voluntad del soberano, no debería abusar de su posición privilegiada por persuadirle consejos y forzarle, sino asesorar e «inclinar al rey» ${ }^{47}$ a tomar las decisiones convenientes para el reino. Asimismo, marca los límites de su oficio con respecto a otras instituciones y cuerpos consultivos señalando que «si han de dejar su auctoridad a los consejos, jueces y ministros, no le queda a él cosa alguna» ${ }^{48}$.

Esta visión idealista de la privanza, según observa Fernández Mosquera, puede resultar incómoda «si el receptor es tentado por la comparación con la realidad representada por Lerma y Felipe III ${ }^{49}$. Efectivamente lo es, si la lectura del texto se efectúa a posteriori, desde

41. Ver Maldonado, Discurso del perfecto privado, p. 15.

42. Quevedo, Discurso de las privanzas, p. 203.

43. Quevedo, Discurso de las privanzas, 205.

44. Ver Lipsius, Los seis libros de las políticas, p. 70.

45. Quevedo, Discurso de las privanzas, p. 205.

46. Quevedo, Discurso de las privanzas, p. 216.

47. Quevedo, Discurso de las privanzas, p. 239.

48. Quevedo, Discurso de las privanzas, p. 211.

49. Fernández Mosquera, 2013, p. 556. 
la perspectiva de la expedición de la cédula de 1612, que equipara el poder del rey al de su ministro, o la de la caída de Lerma cuando su régimen se asocia con la idea de corrupción y la progresiva decadencia de España. Pero esta no es la óptica que adopta Quevedo a principios del siglo ya que, como observa Roncero, por aquel entonces pasa por el momento de ilusión por los cambios que se producen en la vida política española gracias al privado de Felipe III. El momento de la decepción de su política llegará una década más tarde ${ }^{50}$.

\section{Política de Dios: un proyecto de recuperación del estilo de go- BIERNo de FeLIPE II}

La primera parte de la Política de Dios (1616-1621) refleja la opinión crítica que, según señala Roncero, don Francisco se forma sobre el valimiento de Lerma a partir de $1615^{51}$. La composición del tratado coincide con un período en que el duque se convierte en blanco de críticas por sus abusos del poder, intento de igualarse con el monarca, e incluso alejarlo de sus obligaciones regias ${ }^{52}$. Como consecuencia, se desencadena una polémica sobre la legitimidad moral y constitucional del valimiento, en la cual toma parte el padre Juan de Santamaría, pretendiendo reformular el discurso político sobre el privado en su Tratado de república y política christiana (1615). Francesco Benigno y Carmen Peraita han señalado ciertas similitudes en la argumentación del franciscano y Quevedo a favor de la restauración de la autoridad del soberano. Ambos autores abogan por el ejercicio de la realeza personal argumentando que Dios le encargó al monarca la misión de gobernar de modo que este no puede descuidar su oficio ni delegarlo en otro ${ }^{53}$. Tras una lectura atenta de la obra de Santamaría llegamos a la conclusión de que esta pudo ejercer también una influencia en la selección de episodios bíblicos utilizados en la Política de Dios, así como en la concepción quevediana de la privanza, que a finales de la segunda década del xviI sufre cierta modificación.

Al igual que el religioso, don Francisco funda la fuerza persuasiva de su censura del corrupto valimiento de Lerma en llamamientos retóricamente eficaces a una ortodoxia religiosa incuestionable compartida por sus lectores ${ }^{54}$ y recurre a las figuras vetero y novotestamentarias que personifican las faltas y vicios del privado, cuyo nombre evita mencionar. Es posible que la tercera parte del título del tratado quevediano «tiranía de Sátanas», que hace referencia a los abusos de Lerma, se

50. Roncero, 2013, pp. 76 y 88.

51. Ver Roncero, 2009, pp. 150-153; 2013, p. 76.

52. Para más información sobre la crítica del gobierno de Lerma en la primera parte de la Política de Dios ver Peraita, 1996, p. 392.

53. Ver Benigno, 1994, pp. 220-221 y Peraita, 1997, pp. 83-85.

54. Ver Clamurro, 1991, pp. 121-153. 
inspire en la imagen del privado envidioso y soberbio que Santamaría identifica con el demonio:

el apetito del hombre es hidrópico, que cuando más bebe, más sed tiene, y cuanto más alcanza, más desea, tanto le podrán dar, que como a Lucifer, le pongan en deseo y codicia de lo mismo que los reyes poseen ${ }^{55}$.

Quevedo sigue la idea propuesta por el franciscano de vincular la privanza tiránica con el pecado e incluye en la categoría de privados perversos tanto a «el más valido serafín», «el primer consejero que hubo en el mundo» ${ }^{56}$, como al desobediente Adán, el asesino Caín y el traidor Judas Iscariote. También en su lista de buenos privados aparecen los calificados como tales por Santamaría: san Pedro, san Juan Evangelista y Santiago, los apóstoles más cercanos a Cristo que presenciaron el misterio de su Transfiguración ${ }^{57}$, y san Juan Bautista, «espejo de los privados ${ }^{58}$. En este caso don Francisco considera oportuno ampliar dicho grupo solo con la figura de san Pablo.

Al presentar la relación de Cristo con sus apóstoles como un modelo a seguir para el monarca cristiano y su favorito, Quevedo parece olvidarse de sus antiguos avisos de la inconveniencia de que el rey posea muchos validos y aceptar la idea promovida por Santamaría de que es más beneficioso tenerlos varios que uno ${ }^{59}$. Don Francisco expone este concepto en una advertencia dirigida a Felipe IV, en que sugiere establecer una especie de jerarquía de colaboradores reales, cuya cúspide será ocupada por los consejeros de mayor confianza. No obstante, no descarta la posibilidad de que uno de los ministros goce mayor amistad con su señor que otros y la admite siempre y cuando este sepa servirle bien.

Señor, criados han de tener los reyes, unos más cerca de su persona que otros, y la voluntad no será en todos igual, y determinará con más afecto en algunos, y entre ellos podrá ser, que uno solo sea dueño de la voluntad del príncipe: no está en eso el inconveniente, si el rey sabe en que cosas puede

55. Santamaría, Tratado de república y política christiana, p. 228. Quevedo parece parafrasear este pasaje señalando que los privados ambiciosos tratan «como Luzbel de quitarle (al rey) su trono, pues fue aquel Serafín, y su pecado lo será, inventor de las caídas de los poderosos con soberbia» (Quevedo, Política de Dios, p. 91).

56. Quevedo, Política de Dios, p. 73.

57. Ver Santamaría, Tratado de república y política christiana, p. 210.

58. Santamaría, Tratado de república y política christiana, p. 231.

59. Santamaría, Tratado de república y política christiana, p. 215: «porque sea mas fácil el negociar con ellos y cueste menos y sea menos pesado y para que pueda descansar más el príncipe, [...] porque ellos tengan más cuidado y aun más miedo con la competencia, sabiendo que si se descuidaren hay más personas quien pueda encomendarse su lugar, que la opinión de lo contrario los ensoberbece y destruye a su dueño, y también ellos mismos que desvaneciéndose con eso juzgan que su amo no puede vivir sin su ingenio y ayuda y que no hay falta que no se perdone». 
hacer a su criado dueño de su voluntad y el criado como ha de usar deste favor, y estado ${ }^{60}$.

Dicha observación puede interpretarse, por una parte, como un intento de validar la situación que el autor presencia ante la subida al trono de Felipe IV y la llegada al poder de un nuevo equipo de gobierno, donde las funciones del privado se reparten entre dos personajes: Baltasar de Zúñiga, el primer ministro que se hace cargo de los negocios de Estado, y el conde de Olivares, sumiller de corps que goza de la máxima amistad y confianza del monarca. Posiblemente por esta razón, al relacionar en los Grandes anales lo ocurrido en los primeros días de abril de 1621, don Francisco usa la forma del plural refiriéndose a los ayudantes del rey, a los cuales atribuye el nombre de privados, por muy malas connotaciones que dicha palabra tenga por aquel entonces.

Prometen los que hoy sirven (tanto es menester rodear por no decir privados que ha quedado esta voz aciaga y achacosa y formidable) que han de volver al estilo del gobierno al tiempo de Felipe II, nivelándose por su providencia: que los consejos propondrán con libertad; su majestad determinará sin violencia; que ellos tendrán por ejercicio desembarazar el paso a estas mejoras, y quitar el encogimiento a los méritos y el temor a la justicia y verdad ${ }^{61}$.

Por otra parte, la existencia de varios privados puede explicarse a la luz del programa de reformas del equipo de Olivares, orientado a recuperar en el ámbito administrativo la herencia del Rey Prudente ${ }^{62}$. Cabe recordar que Felipe II desde el principio de su reinado se rodeó de varios favoritos, cambiando con el paso de tiempo los unos por los otros. A pesar de que estos pudieran influir en las decisiones reales, como señala Elliott, su participación en la gobernación de la monarquía no implicaba la debilidad del monarca, sino que constituía una respuesta a los problemas que presentaba la extrema burocratización de la administración española ${ }^{63}$. El conjunto de los colaboradores más cercanos del rey, que menciona Quevedo, puede entenderse como una alusión al consejo privado de Felipe II, la llamada Junta de Gobierno «situada por encima de las demás instituciones de gobierno y orientada a ayudarle a definir la política a seguir y acciones de los consejos reales» ${ }^{64}$. En cambio, la idea de la primacía de uno de los privados posiblemente remite a la figura de Cristóbal de Moura, el ministro más poderoso del

60. Quevedo, Política de Dios, p. 103.

61. Quevedo, Grandes anales, pp. 77-78.

62. En la instrucción secreta que Olivares dirige en 1624 a Felipe IV le presenta la visión de organización interna del gobierno de Felipe II y recomienda al joven monarca imitar a su abuelo en el trato con los grandes y el cuidado de reducir su poder. Ver Elliott, 2002 , p. 150.

63. Ver Elliott, 1997, pp. 892-896; Feros, 2002, pp. 22, 101.

64. Feros, 2002, pp. 68-69. 
Rey Prudente e intermediario entre este y otros oficiales e instituciones, incluida la Junta de Gobierno. Según sostiene Antonio Feros, la estrecha relación que mantenía Moura con Felipe II sirvió de precursor del tipo de relaciones entre el monarca y su valido, características de los reinados de sus sucesores ${ }^{65}$. Quevedo, como admirador del gobierno del Rey Prudente, no se opone a ellas. Lo que desaprueba es la existencia de validos ambiciosos y corruptos como el duque Lerma o Uceda, cuya antítesis percibe en la postura de Olivares. Y es en él en quien pone sus esperanzas de renovación política y moral, tal como lo indica en la nota dedicatoria: «dar a leer a v.E. este libro es la mejor diligencia que puede hacer el conocimiento de su integridad, para darse por entendido del cuidado con que asiste al rey nuestro señor, en valimiento ni celoso ni interesado" ${ }^{66}$.

El contexto histórico-político de la Política de Dios determina inevitablemente las coordenadas sobre las cuales don Francisco estructura su reflexión sobre la privanza. Valiéndose de su propia experiencia con el antiguo régimen, el autor advierte al joven rey del peligro que constituyen para él los validos ambiciosos, censura la negligencia de su difunto padre y anima a Felipe IV a ejercer personalmente la soberanía. Apelando a la ejemplaridad de Cristo, que vino a la tierra para enseñar a los reyes, don Francisco intenta convencer a su lector de que el poder pertenece exclusivamente al monarca y este debe rodearse de ministros que no obstaculicen el desempeño de su misión. Los que quieran apropiarse de las prerrogativas regias merecen un tratamiento severo como "san Pedro, su valido, su sucesor, porque le quiso excusar los trabajos, y le buscaba el descanso, le llamó (Cristo) Satanás, y le echó de sím ${ }^{67}$. Quevedo insiste en que el oficio real no admite sustituto alguno, sino que requiere una dedicación completa por parte del soberano, en lo que parece aludir a las palabras del padre Santamaría ${ }^{68}$ :

Reinar es velar, quien duerme no reina: rey que cierra los ojos, da la guarda de sus ovejas a los lobos, y el ministro que guarda el sueño a su rey, le entierra, no le sirve, le infama, no le descansa, guárdale el sueño, y piérdele en la ruina y desolación de los reinos ${ }^{69}$.

El autor también retoma algunos de los temas planeados en su visión del valimiento del Discurso de las privanzas tales como la sugestiva imagen del sol y la luna que sirve para determinar los límites del poder del favorito e impedir que este emule a su señor. Dicho concepto se

65. Ver Feros, 2002, pp. 98-100.

66. Citado por Peraita, 1997, p. 1.

67. Quevedo, Política de Dios, p. 50.

68. Santamaría, Tratado de república y política christiana, p. 237: «Como muerto está el rey que deja a otro lo que él puede hacer, le toca el oficio: y así como no cumpliría bien con sus obligaciones, si quisiese traer a sí solo el gobierno de todo su reino, así mucho menos si todo lo echase de sí, y fiase de otros».

69. Quevedo, Política de Dios, p. 80. 
ilustra con el ejemplo de san Juan Bautista, a quien los israelitas confundían con Mesías al no saber

diferenciar al fuego de la centella, y al Sol del Lucero, que es dadiva de sus rayos, y viene a traer nuevas del día, y a ganar las albricias de la luz al mundo, su vida no la gastó en otra cosa que en desengañarlos, y enseñarles la verdad ${ }^{70}$.

Quevedo avisa de la inconveniencia de que el valido se familiarice públicamente con el rey aventurando su reputación, pero admite un trato de confianza en lo privado: «No peligran tanto los Reyes que favorecen en secreto como hombres; y van aventurando los que por su gusto fuera de obligación favorecen en público» ${ }^{71}$. Refiriéndose a las funciones propias del valido don Francisco hace hincapié en la «diferencia entre dar consejo, y persuadir consejo ${ }^{72}$, que hace la voluntad del rey esclava de su propio criado. Recuerda que a este no le conviene controlar el proceso consultivo ni dominar la toma de decisiones reales, sino actuar como un simple intermediario entre el monarca y los consejos: «Sirva el criado, y merezca, no mande, no sea arbitro entre el rey y los consejos, traiga al rey las consultas y los papeles, y alivie al rey el trabajo del mudar las bolsas de los consejos de una parte a otra, y de abrir los pliegos, de disponerse a los aciertos con su parecers ${ }^{73}$.

Vuelve a abordar la cuestión de las audiencias de los privados, justificando su derecho a concederlas por el hecho de que Cristo pusiera en el animo de los apóstoles el darlas. No obstante, se opone a la separación entre el rey y su reino que puede causar el dejar las audiencias exclusivamente en manos de los validos $y$, aludiendo indirectamente al caso de Lerma, evoca las palabras de Cristo: «dejad que los niños se acerquen a mí» para argumentar sobre la necesidad de que las dé también el mismo monarca:

Dar audiencia los ministros es forzoso, y pueden cometer gran crimen y escándalos en el modo de darla, por ser la acción de singular majestad en los reyes, y en España, y Castilla particularmente, no hacer otra con los vasallos, en que personalmente el rey ejercite la jurisdicción y soberaní ${ }^{74}$.

El escritor censura el escandaloso comportamiento de los privados vanos y malintencionados que, al igual que Satanás en el desierto, pretenden tentar al príncipe con sus memoriales o enriquecerse a costa de su señor como el «consejero Iscariote», quien fingiendo el cuidado de los pobres quiso vender el ungüento que María Magdalena había ofreci-

70. Quevedo, Política de Dios, p. 102.

71. Quevedo, Política de Dios, p. 70.

72. Quevedo, Política de Dios, p. 115.

73. Quevedo, Política de Dios, p. 106.

74. Quevedo, Política de Dios, p. 99. 
do a Cristo. Al recordar el episodio de una mujer que tocó la vestimenta de Cristo de modo que de este salió la virtud, Quevedo reprocha a los ministros la costumbre de tomar a hurtadillas la recompensa por los servicios prestados a la corona y alabando la conducta de san Pedro les recomienda un ideal del servicio desinteresado y laboriosidad: «tan lejos ha de estar el pedir del ministro, que aun por ser pedir limosna pedir, ha de trabajar primero en su ministerio que pedirla ${ }^{75}$. En el ambiente de críticas que recibe Lerma por buscar enriquecimiento de los suyos, a diferencia de lo postulado en el Discurso de las privanzas, don Francisco cuestiona la oportunidad de colocar en los altos cargos y beneficiar con mercedes a los parientes y hechuras de los validos. Y apoya su oposición al clientelismo en la enseñanza de Cristo, según la cual, quien no aborrece a su familia no puede ser discípulo suyo.

Al fundar el ideal del buen privado en los ejemplos exclusivamente evangélicos, como observa Carmen Peraita, Quevedo se reviste de una autoridad moral absoluta y abandona el criterio político a la hora de analizar el sistema de valimiento ${ }^{76}$. Así, la distinción entre la privanza duradera y la perecedera, que proponía en el Discurso de las privanzas, se sustituye por otra, basada en los valores estrictamente éticos: la buena privanza que ejercen los ministros virtuosos y la mala a cargo de los viciosos. Según se desprende de la Política de Dios, el vicio no puede considerarse más como una garantía de la conservación del poder del valido. El modelo que se le propone a seguir abarca una serie de virtudes, por excelencia, cristianas como la humildad, caridad, obediencia y misericordia, cuya utilidad política no es objeto de reflexión de don Francisco.

El autor también se distancia de sus anteriores opiniones sobre la elección del privado. Al plantear este tema en la Política de Dios, en lugar de disuadir al rey el apartamiento del favorito caído en desgracia, admite que aquel tiene derecho a equivocarse a la hora de designar a sus ministros e insiste en la necesidad de subsanar su error con derribar al mal consejero y expulsarlo de la corte, como lo hizo Dios con el serafín rebelde y el primer hombre. Asimismo, avisa de las consecuencias de la excesiva tolerancia del monarca para con su valido porque

rey que disimula delitos en sus ministros, hácese participe dellos, y la culpa ajena la hace propia: tiénenle, por cómplice en lo que sobrelleva, y los que con mejor caridad le advierten, por ignorante, y los mal intencionados, que son los mas, por impío 77 .

Además, coincide con Santamaría ${ }^{78}$ al pronunciarse a favor de castigar al favorito que ha abusado de la confianza de su señor. Es de recordar que ya en el Discurso de la privanzas Quevedo señala la necesidad

75. Quevedo, Política de Dios, p. 119.

76. Ver Peraita, 1996, p. 393.

77. Quevedo, Política de Dios, p. 73.

78. Santamaría, Tratado de república y política christiana, p. 232. 
de castigar la maldad para mostrar que uno no tuvo la culpa al consentirla, pero en este caso se refiere a la condena de los falsos amigos del privado $^{79}$. En la Política de Dios, en cambio, recomienda explícitamente penalizar las faltas de los validos malvados animando al rey a imitar el ejemplo de Cristo, quien no dudó en castigar públicamente a sus ministros. De esta manera, don Francisco no solo clama por hacer justicia a Lerma, sino que también predice la ejecución de su protegido Rodrigo Calderón, ocurrida el 21 de octubre del mismo año, que relata con detalles en los Grandes anales.

La experiencia del autor con el gobierno de Lerma le lleva a retocar la teoría del perfecto privado anteriormente expuesta en el Discurso de las privanzas y destacar la necesidad de imponer límites al poder del favorito real. En ningún momento don Francisco pone en cuestión la conveniencia de la existencia del mismo, pero insiste en su obligación de cumplir debidamente con su función y no extenderse más de lo que da licencia su cargo. Las reformas iniciadas por el gobierno de Olivares le permiten creer a Quevedo que el ideal de la privanza postulado en su tratado encontrará una realización práctica y provechosa para la patria. Con esta esperanza se lo envía al conde-duque unos cinco días después del cambio de régimen, guiado también por la intención de ganarse la simpatía del valido, a cuya disposición dejará su pluma a lo largo de la década siguiente.

\section{COMO HA DE SER EL PRIVADO: UN ESPEJO DE VALIDOS ESCENIFICADO EN HONOR a Olivares}

La información proporcionada por Mérimée de que la comedia Cómo ha de ser el privado andaba en marzo de 1624 en repertorio de Roque de Figueroa y Mariana de Olivares ${ }^{80}$ permite fijar la fecha de su composición entre 1623 y 1624. La aparición de la pieza corresponde con el momento de integración de Quevedo en el equipo de Olivares, una vez regresado a Madrid del destierro en la Torre de Juan Abad en marzo de $1623^{81}$. Por este motivo, Pablo Jauralde no duda en calificarla como una obra de circunstancias creada por la necesidad de don Francisco «de medrar en favores cortesanos» ${ }^{82}$. La temática de la obra, creada por encargo del privado real, se inscribe perfectamente en el marco de la campaña de propaganda, promovida por el mismo y orientada a recuperar la grandeza de España. Su trama abunda en alusiones a los sucesos ocurridos a principios del reinado de Felipe IV y consta de tres hilos argumentativos, de los cuales el principal lo constituye una lección de buen gobierno que el marqués de Valisero (anagrama de Olivares) ofrece a su inexperto señor don Fernando de Nápoles (Felipe

79. Quevedo, Discurso de las privanzas, 249.

80. Citado por Blecua, en Quevedo, Obra poética, p. 149.

81. Ver Elliott, 1982, p. 229.

82. Jauralde, 1998, p. 586. 
IV). Le acompañan dos historias amorosas secundarias: el cortejo del príncipe de Dinamarca (Carlos Estuardo) a la infanta Margarita (María de Austria) y la relación del rey napolitano (Felipe IV) con una dama de su corte (Francisca de Tavora ${ }^{83}$ ), que terminan con la separación de las respectivas parejas.

A la vez de ensalzar la figura del soberano español, Quevedo desarrolla en su obra una imagen francamente adulatoria de su favorito, quien a la muerte de Baltasar de Zúñiga en 1622 se convirtió en el único privado de Felipe IV. Fue por aquel entonces cuando el poder omnímodo de Olivares empezó a despertar protestas de la gran nobleza, consciente de las semejanzas de su estrategia de reforzar la autoridad real y la táctica de aislamiento del monarca practicada por Lerma, que el conde-duque había propuesto rectificar. La revitalización del cargo de caballerizo mayor ${ }^{84}$ y la creación de otros como los de gentilhombres censores, desempeñados por los allegados del valido, constituían también a los ojos de los cronistas áureos un intento de limitar el acceso al rey ${ }^{85}$. El agente inglés James Howell registró el crecimiento de la oposición antiolivarista a principios de 1623 , mencionando en sus cartas palabras de descontento y crítica que circulaban en la corte. En julio del mismo año se montó incluso una conspiración de aliados de los Sandovales que tenía por objetivo hechizar al rey y envenenar a su privado $^{86}$. En vista de estas circunstancias, podemos suponer que la composición de la comedia quevediana fue motivada, más que por la mera intención propagandístico-encomiástica o la de demostrar la fidelidad del autor al régimen olivarista ${ }^{87}$, por la idea de depurar la imagen del

83. Ver De Armas, 2004, pp. 16-17. Por su parte, Hernández Araico, 1999, p. 465, identifica la dama con la famosa actriz la Calderona, de cuya relación con Felipe IV nació el 17 de abril de 1628 el hijo ilegítimo del rey, Juan José de Austria.

84. Los cargos cortesanos de sumiller de corps y caballerizo mayor les aseguraban a Lerma y Olivares el acceso directo al monarca tanto en el interior como en el exterior del palacio. Ver Feros, 2002, pp. 328-329.

85. Ver Enciso Recio, 2005, p. 114.

86. Ver Suárez y Gallego, 1986, p. 451.

87. Ver Urrutia, 1982, p. 185; Elliott, 1982, pp. 233-239; Hernández Araico, 1999, p. 463; Iglesias, 2005; Arellano, 2011, pp. 46-54. Por su parte, Iglesias apunta a un cierto enfriamiento de las relaciones entre Quevedo y Olivares a finales de la década de los veinte, cuyos indicios cree encontrar en la comedia. A tal fin sirve, en su opinión, el hecho de atribuir a Valisero las altas cualidades y virtudes que Olivares no poseía en realidad y la selección de temas con que se enriquece la segunda versión de la pieza: las poco exitosas reformas económicas de Olivares (1627), el empeoramiento de la situación del ejército español en el conflicto de Mantua (1628) y la pérdida de la flota de plata (1628). Ver Iglesias, 2005, pp. 281-285 y 2013, pp. 83-84, 86-87. Cabe señalar que la estrategia de idealizar al valido, que el autor utiliza también en el Discurso de las privanzas, no implica una censura velada de sus faltas. Además, a lo largo del texto de la comedia se pretende desmentir la responsabilidad del privado por los fiascos de la política del momento. No obstante, no podemos descartar que el público cortesano pudiera interpretar los versos laudatorios de la pieza como una crítica del conde-duque, lo cual sería la razón suficiente para no ponerla en escena. 
primer ministro y justificar su posición en la corte, así como rehabilitar el nombre de «privado», como sugiere Elliott ${ }^{88}$.

El intento de legitimar el papel del favorito real resulta más patente, si nos fijamos en el contexto de la posterior reelaboración de la pieza, realizada entre 1628 y 1629. Esta posiblemente constituye una respuesta al incremento de la crítica antiolivarista y la aparición del anónimo Memorial de los Caballeros de España dirigido a Felipe IV en junio de 1629. Sus autores lanzan un violento ataque contra el gobierno del conde-duque, que definen como tiránico, invitan al monarca a apartar a su valido y a gobernar por ministros elegidos de entre los grandes, de modo que los negocios de Estado los atiendan unos pocos y no uno solo porque «culpa es del príncipe sujetarse a uno y fiar de uno ${ }^{89}$. Recordando los gloriosos ejemplos del abuelo y bisabuelo del rey, dicho manifiesto retoma los argumentos usados por Quevedo en 1621, los cuales el autor parece callar mientras forma parte de la camarilla de intelectuales de la corte, tanto en el año 1623 como inmediatamente después de su segundo destierro en 1628. En cambio, una vez desilusionado de la política de Olivares, vuelve a plantear en la segunda parte de la Política de Dios la idea inspirada en la obra de Santamaría sobre la conveniencia de que el rey tenga varios privados ${ }^{90}$. Como indica Jaramillo Cervilla, la actitud de don Francisco hacia la figura del valido no presenta (un criterio fijo sino coyuntural ${ }^{91}$ y depende de los altibajos en sus relaciones con el conde-duque, de modo que en los momentos de crisis censura su poder, pero en los de mayor acercamiento le ayuda con sus escritos a legitimarlo. La comedia Cómo ha de ser el privado la clasificamos en el segundo grupo de textos, pues, en ningún momento el autor pone en tela de juicio la existencia de un único favorito real, es más, presenta este tipo de régimen como el más provechoso para el Estado.

Varios críticos sugieren interpretarla como una representación teatral de un tratado de perfecta privanza. Sarah Voinier detecta en su texto ciertas similitudes con el modelo teórico expuesto en el Discurso de las privanzas $^{92}$. Por su parte, Henry Ettinghausen e Ignacio Arellano proponen una lectura de la comedia a la luz de la teoría desarrollada en la Política de Dios ${ }^{93}$. En nuestra opinión, al llevar a la escena la figura del estadista desinteresado y totalmente entregado al servicio de su rey don Francisco reúne el ideario formulado en ambas obras. A continuación,

88. Ver Elliott, 2000, p. 168.

89. Elliott y Peña, 1979-1981, vol. 2, p. 8.

90. Quevedo desaconseja al rey confiar en un solo privado y recurriendo al ejemplo san Pedro y san Pablo, los dos validos de Cristo, afirma: «es utilísimo al supremo ministro que el monarca, después de su elección, elige otro que no le sea desigual y se atreva a contradecirle en su cara, y a reprenderlo ásperamente delante de todos» (Quevedo, Política de Dios, p. 278).

91. Jaramillo Cervilla, 1981, p. 87. Esta opinión la comparte Roncero, 1988, p. 128.

92. Ver Voinier, 2010.

93. Ver Ettinghausen, 2003, p. 49 y Arellano, 2009, pp. 212-218. 
intentaremos señalar los conceptos de que se sirve el autor para construir el personaje del marqués de Valisero y determinar el papel que este desempeña en la corte y dentro del sistema administrativo del Estado.

La figura del privado perfecto, junto con la del rey perfecto, constituye el tema central de la pieza. La acción dramática empieza con la subida al trono del joven monarca, entre cuyas primeras resoluciones está la de buscarse un valido. Al explicar el motivo de su decisión en un comentario aparte, don Fernando vuelve a repetir los argumentos presentados en el Discurso de las privanzas sobre la necesidad de compartir el peso del gobierno de la monarquía con un consejero íntimo. También sigue la línea trazada en su primera obra seria apuntando a la inconveniencia de repartir la responsabilidad por el Estado y su propia confianza entre varios ministros, con lo cual se distancia del ideario presentado en la Política de Dios.

$\begin{array}{ll}\text { Rey (Aparte) } & \text { Para aliviar este peso } \\ & \text { he menester un valido. } \\ & \text { Rey que de nadie se fía, } \\ & \text { entre los vasallos buenos } \\ & \text { poco vale, y vale menos } \\ & \text { el que de todos confía. } \\ & \text { De un hombre me he de fiar (vv. 127-133). }\end{array}$

Tras examinar a los tres candidatos: el Almirante, el Conde y el Marqués, el rey nombra como su privado a este último, que desde el primer momento se presenta como un estoico sabio y desinteresado, libre de toda ambición, digno del nombre de «Séneca español» (v. 2243), que le otorgará más adelante el propio soberano. Dichas alabanzas, por una parte, se inscriben en el marco de la estrategia aplicada en el Discurso de las privanzas, basada en la atribución de las virtudes estoicas a Lerma, por otra, reflejan la personalidad del conde-duque, quien había hallado los principios directores de su vida en el mismo estoicismo cristianizado de Lipsio ${ }^{94}$. Es de recordar que la abnegación de Olivares era considerada por sus contemporáneos como su máxima virtud e incluso llegó a representarse gráficamente en el frontispicio del poema heroico El Fernando o Sevilla restaurada (1632) del conde de la Roca, personificado en la figura de Atlas «desnudo de interés». Posiblemente a este símbolo alude don Francisco, cuando hace al rey de la comedia anunciar su elección con las siguientes palabras:

$\begin{array}{ll}\text { ReY } & \text { Vos, marqués, sois elegido } \\ \text { por mi Atlante verdadero, } \\ \text { cuyos hombros han de ser } \\ \text { mi descanso y compañía (vv. 167-170). }\end{array}$

94. Ver Elliott, 1982, p. 239. 
En nuestra opinión, el pasaje citado no debería interpretarse en términos de la supuesta homosexualidad del monarca, como sugiere Frederick de Armas ${ }^{95}$, sino a la luz del ejemplo de Alcides, proporcionado por Quevedo en el Discurso de las privanzas. Dicha imagen sufre en el texto de la comedia una deformación debida a la inversión de papeles del rey-Atlante y el privado-Alcides, la cual revela la inmadurez e inexperiencia política del joven don Fernando. Es el soberano quien ha de sostener el firmamento, o sea, la carga de la república, mientras que su ministro, como el héroe mitológico, no debe más que descansarle de su trabajo a ratos pero en ningún caso sustituirle. Este ideal de relación entre el rey y su valido se consigue en el resultado de la labor educativa del marqués de Valisero, quien le devuelve al soberano su papel correspondido, de lo que informa, recurriendo al lenguaje metafórico, en su relación de la cabalgata por las calles de Nápoles, celebrada con motivo de la entrada solemne de los dos Atlantes: don Fernando y Carlos de Dinamarca.

El desinterés de Valisero se manifiesta a lo largo de la obra con su modestia de las costumbres, austeridad y desprecio por la ostentación material, que muestra a la hora de negarse a aceptar del rey otro premio por sus servicios que el dinero para hacer su propio sepulcro. Otra faceta de la virtud de abnegación la constituye la falta de ambición de gobernar, en que hace hincapié don Francisco en el Discurso de las privanzas: «no ha de buscar el hombre a la privanza, que es señal de que la ha menester a ella, y la privanza solo ha menester al que no tiene della necesidad ${ }^{96}$. Este ideal lo pone en práctica Olivares al comienzo del reinado de Felipe IV cuando cede el cargo de primer ministro a su tío Baltasar de Zúñiga y acepta colocarse en un segundo plano. Quevedo pondera esta postura en los Grandes anales ${ }^{97}$ y, más tarde, la recuerda en la comedia con las palabras del marqués de Valisero, quien se excusa de recibir el nombramiento del privado:

$\begin{array}{ll}\text { Marqués } & \begin{array}{l}\text { Señor, otros hombros fieles } \\ \text { de más fuerza que los míos } \\ \quad[\ldots]\end{array} \\ & \begin{array}{l}\text { el duque de Sartabal } \\ \text { de experiencia sin igual } \\ \text { de más talento que el mío (vv. 193-194, 202-204). }\end{array}\end{array}$

95. Ver De Armas, 2004, p. 14.

96. Quevedo, Discurso de las privanzas, p. 198.

97. «Tal elección aconsejó a su majestad la modestia del conde de Olivares, a quien bastó el ánimo a quitarse para otro lo que no ha podido caber entre padres e hijos. (Para ver cuánto talento sobraba al conde de Olivares para este ministerio, no es menester más de ver el conocimiento con que le dejó pasar a otro); que quien sabe despreciar el poder es el benemérito, y el que le codicia es el temerario. En el uno es gloria lo que deja y en el otro peligro lo que tiene. Lo que es el conde de Olivares, todos lo saben; lo que sabe ser, todos lo ven; hablar más en su persona parecerá más negociar que referir, y habrá ánimos tan ejecutivos que les parecerá tarde el advertirlo» (La versión de las primeras dos ediciones de los Grandes anales escritas entre 1621 y 1624 citada por Roncero, 1988, p. 136). 
Con esta retórica del menosprecio de las mercedes y privilegios cortesanos, Valisero insiste en compartir el poder con su tío, a quien adjudica el despacho de los negocios de Estado, mientras que él mismo se conforma con acompañar y servirle al monarca, disfrutando de su favor pero sin permitirse un trato familiar con él. El marqués se opone radicalmente a la idea de la amistad entre el monarca y su valido fundada en la igualdad entre ambos, que servía de fundamento de la teoría de legitimación de la privanza de Lerma. De ahí su desaprobación del concepto de la comunión de las voluntades y la unión de las almas repartidas en dos cuerpos que expone don Fernando, siguiendo la definición humanista de la amistad ${ }^{98}$. Al igual que Santamaría ${ }^{99}$, Quevedo no admite igualdad entre el rey y su vasallo, por lo cual hace al valido de su comedia responder a la propuesta del rey haciéndole ver las limitaciones de su función como favorito. Valisero marca una clara distancia entre sí mismo y su señor recurriendo a la conocida imagen emblemática de la luz participada:

$\begin{array}{ll}\text { Marqués } & \text { porque un privado } \\ \text { que es un átomo pequeño } \\ \text { junto al rey, no ha de ser dueño } \\ \text { de la luz que el sol le ha dado (vv. 249-252). }\end{array}$

Siguiendo el modelo establecido en el Discurso de las privanzas, Valisero define su propio papel como el de cun instrumento / por donde pasa el aliento / a la voluntad del rey» (vv. 254-256). Reconoce ser un simple colaborador al que le toca aconsejar pero no decidir en vez del monarca, más predestinado para eso por contar con la ayuda de dos ángeles de la guarda ${ }^{100}$. El perfecto privado nunca impone su opinión, sino que escucha y presenta su punto de vista cuando se lo piden. Esta postura la adopta el marqués durante la reunión con el rey y la infanta sobre la posible unión dinástica con Dinamarca, en la cual el mismo subraya su papel secundario y auxiliar:

MarquÉs

Señor,

pues que libertad me has dado,

mi sentimiento diré

con respeto de vasallo,

con atención de ministro

y con valor de cristiano (vv. 728-733).

98. Ver Feros, 2002, p. 222.

99. Santamaría, Tratado de república y política christiana, p. 207: “y como la amistad ha de ser entre iguales, no parece que la pueden tener los que son vasallos, o criados con su rey, y señor, al cual han de mirar, y tratar con gran reverencia, respetando siempre su real majestad».

100. Esta idea la plantea también Maldonado, Discurso del perfecto privado, p. 4 y Santamaría, Tratado de república y política christiana, p. 217. 
En la historia de las fallidas negociaciones de boda de la infanta Quevedo nos deja ver que Valisero ejerce la función de intermediario entre el rey y los cuerpos consultivos, que se atribuye al valido en el Discurso de las privanzas y en la Política de Dios. El marqués transmite a don Fernando las condiciones que sugieren poner a don Carlos la junta de teólogos y el Consejo de Estado, sin pretender excluirlos del proceso de la toma de decisión real. Al mismo tiempo, le abre los ojos a lo peligroso que es pactar con los herejes, capaces de romper con la palabra dada, y a la inconveniencia de situar el interés político por encima del celo religioso. Dicho razonamiento convence al monarca, quien reconoce haberse inclinado desde el principio a rechazar al pretendiente danés. De manera similar, el valido se limita a ser un enlace entre el rey y su pueblo, mantiene las puertas del palacio abiertas a los que piden audiencias y no deja de concederlas incluso cuando pasa por una tragedia familiar. Sin embargo, no sustituye completamente a su señor en atender las quejas y peticiones de los súbditos, sino que siempre le remite la resolución final de los casos particulares.

Además de mostrar la prudencia del valido, el episodio de las audiencias sirve también para destacar lo duro e ingrato que es su oficio. Este implica una dedicación completa a los asuntos de Estado, la obligación de proteger la imagen del rey e incluso la de asumir los errores que este comete. Tal muestra de lealtad la da Valisero en la conversación con un soldado que, pidiendo una recompensa por sus servicios, se queja de la injusticia de don Fernando. Dicha escena dramatiza el concepto de la privanza que el mismo marqués expone en la primera jornada, cuando a regañadientes acepta su cargo:

$\begin{array}{ll}\text { Márques } & \text { es linaje de castigo, } \\ & \text { que me das, con merced tal, } \\ & \text { todo el reino por fiscal } \\ & \text { y con fiscal, enemigo. } \\ & \text { Por un escudo me pones, } \\ & \text { sin que haya excepción, en quien } \\ & \text { rigurosos golpes den } \\ & \text { comunes murmuraciones (vv. 173-180). }\end{array}$

El descontento del vulgo, por una parte, y la envidia de los poderosos, por otra, constituyen los dos mayores peligros para la estabilidad de la privanza $y$, a la vez, los instrumentos con que la fortuna puede hacer bajar al favorito real. A diferencia del Discurso de las privanzas, esta vez Quevedo no identifica el ciego destino con la caprichosa voluntad del rey, dando a entender que este no duda de la fidelidad de su valido y aprecia sus servicios y dedicación. A pesar de las declaraciones iniciales de Valisero de que la fortuna lo deja expuesto «a ser blanco sin segundo / de sus envidias y quejas» (vv. 271-272), ninguno de estos tópicos 
literarios recurrentes en las comedias de la privanza ${ }^{101}$ tiene un impacto significativo en su carrera política. La posición del privado no está amenazada por las murmuraciones del pueblo que se queja de la subida de precios, ante lo cual el marqués considera oportuno únicamente aconsejarle que tenga paciencia. Tampoco la envidia cortesana pone en peligro su futuro en la corte, pues, los dos rivales de Valisero por la privanza, el Conde y el Almirante, resultan ser sus grandes admiradores, que a cada paso alaban la acertada elección del rey y las cualidades de su favorito.

La fuerza que rige el destino del privado no es la ciega fortuna sino la Providencia, concepto que no suele formar parte de los tratados del perfecto privado. El autor pretende vincularlo con la idea pagana del fatum haciendo de la imagen emblemática del roble que resiste a los vientos de la fortuna ${ }^{102}$, proyectada en el primer acto, una especie de presagio de la muerte del hijo de Valisero, que se atribuye a la mano de Dios. En estos términos la interpreta el Almirante, quien avisa al marqués del triste suceso, y al consolarlo apunta a la virtud estoica que debe hacerle inmune a este duro golpe: «y así debe el prudente y el cristiano / recibir los trabajos mientras vive / con la misma igualdad que bien recibe» (vv. 1151-1153). La apatheia que muestra el valido en el ámbito privado se extiende al campo de lo público, pues, no deja de conceder audiencias ni siquiera el día de recibir la mala noticia. No obstante, si analizamos la pieza quevediana como una representación dramática de la teoría del perfecto privado, esta escenificación de la idea de la virtud parece poco exitosa. Quevedo resalta aquí solamente su dimensión moral, sin profundizar en su valor político, mientras que en el Discurso de las privanzas le atribuía la capacidad de proteger al favorito de las consecuencias de la inconstancia de su oficio. Dicha cuestión en la comedia no se llega a plantear.

En la pieza se aborda, en cambio, otro de los temas fundamentales de los manuales de privados, el de la formación moral y política del monarca que está a cargo de su ministro. Quevedo retoma el proyecto trazado de una manera muy general en el Discurso de las privanzas, que obligaba al valido a guiar la voluntad del rey y animarle a seguir ejemplos virtuosos, y lo desarrolla en la comedia a fin de reflejar el plan de Olivares de preparar al joven Felipe IV a hacerse cargo de sus obligaciones reales ${ }^{103}$. A partir de las primeras escenas el autor resalta el papel que desempeña el valido en la orientación del gobierno de don Fernando al ayudarle a elegir un sobrenombre. El marqués le desaconseja adoptar el de «santo», dando a entender que el Estado no requiere de otro monarca con el apelativo ni cualidades similares a los de Felipe III, cuyo gobierno vuelve a censurar al identificar al padre del rey de la comedia con Juan II de Castilla y reprocharle que se sujetó dema-

101. Ver Ferrer, 2004, p. 168.

102. Ver Armas, 2013, p. 111.

103. Ver Elliott, 1990, pp. 183-184. 
siado en su privado ${ }^{104}$. A continuación, le sugiere al monarca otros dos apodos, los de Sabio y Prudente, apelando de esta manera a las figuras de grandes gobernantes Alfonso X y Felipe II, cuyas historias Olivares incluyó en la lista de lecturas para el joven Felipe $\mathrm{IV}^{105}$.

El rey de la comedia decide elegir el sobrenombre de justiciero recordando, como lo hace el mismo Quevedo en la Política de Dios, que la justicia es una de las principales prerrogativas y virtudes del monarca cristiano ${ }^{106}$, a quien corresponde castigar severa y públicamente a sus ministros deshonestos y corruptos. Estas declaraciones del monarca remiten claramente a las medidas reformadoras tomadas al inicio del nuevo gobierno como la ejecución de Rodrigo Calderón. Sin embargo, no deberían interpretarse como indicios de la supuesta crueldad del soberano, sino a la luz de los intentos de Felipe II de rehabilitar al rey Pedro I de Castilla ${ }^{107}$, a los cuales alude el ficticio don Fernando al adoptar el apodo de Justiciero: «Al rey don Pedro le dieron / los que con causa quisieron / desmentir el del Cruel» (vv. 90-92). La mención de don Pedro, uno de los monarcas preferidos de los dramaturgos del siglo XvII, no parece nada fortuita en la pieza. Según sostiene Sánchez Sánchez, la introducción de este personaje en la escena española respondía a «la necesidad de fortalecer e imponer un sistema de valores en una sociedad en crisis, que se suponía precisaba de un rey protector de la justicia y con poder absoluto» ${ }^{108}$. Y no podemos dudar de que este es precisamente el objetivo que persigue don Francisco en su obra.

De Armas y Arredondo llaman la atención a la evolución del personaje de don Fernando a lo largo de la comedia ${ }^{109}$. El rey madura y completa su educación moral y política, asistido por su fiel ministro. Es este quien aconseja bien al monarca atrapado en el dilema de elegir entre la razón de Estado cristiana y la conveniencia política a corto plazo, que supone la posible alianza con el hereje príncipe de Dinamarca. Le ayuda a tomar una decisión acertada al recordarle la obediencia que debe a la ley divina y la misión de defender la fe realizada por sus antepasados. Aprendida esta lección, el rey no necesita más asesoramiento para darse cuenta de los provechos que ofrece el matrimonio de su hermana con el católico príncipe de Transilvania ${ }^{110}$ y decide por sí mismo darle su

104. Este mismo disfraz histórico de Juan II de Castilla y Álvaro de Luna lo utiliza el padre Santamaría para censurar la excesiva dependencia de Felipe III del duque de Lerma. Ver Santamaría, Tratado de república y política christiana, p. 234.

105. Ver Elliott, 1990, p. 184.

106. Ver Arellano, 2009, p. 213.

107. Felipe II mandó eliminar el apelativo de cruel de la estatua de Pedro I en la Sala de los Reyes en el Alcázar de Segovia. Ver De Armas, 2004, p. 12.

108. Sánchez Sánchez, 2011, p. 127.

109. Ver De Armas, 2004, p. 9 y Arredondo, 2015, p. 21-23.

110. La evocación de la figura del príncipe de Transilvania en el texto de la comedia debe interpretarse en el marco de estrategia de máscaras que usa Quevedo para cubrir la identidad de sus personajes. No hace referencia al personaje histórico de Gabriel Bethlen, calvinista y cabeza de la insurrección antihabsburga involucrada en la Guerra de los 
mano. De manera similar el marqués apoya a su señor cuando este lucha consigo mismo para vencer la atracción sentida por Serafina y someter sus apetitos al imperativo de la razón ${ }^{111}$. Es a Valisero a quien el monarca pide consejo en materia amorosa y sigue su recomendación de no fingir enojo sino entablar una relación galante y virtuosa con la dama. Librándose de la pasión, don Fernando da una muestra de autodominio, cualidad necesaria al rey tanto en lo privado como en el manejo de los asuntos de Estado.

La evolución de la postura política y moral del rey se ilustra con dos figuras emblemáticas. La primera la incluye Valisero en su relación de las cañas convocadas con motivo de la visita del príncipe danés, donde presenta a don Fernando como un excelente jinete que rige a su caballo con el freno y las riendas, símbolos de la ley y la razón que deberían guiar cualquier acción política ${ }^{112}$. La segunda aparece en el parlamento de don Fernando, quien al justificar su decisión de terminar la relación con Serafina se compara con un bajel que atravesando el piélago de amor perdió el rumbo, pero ahora se navega con la sonda ${ }^{113}$, metáfora de la virtud de la prudencia que guía al rey. Dichas composiciones simbólicas no son las únicas que pudieron servir de inspiración al autor de la comedia. Curiosamente, el planteamiento general de la trama, que Luciana Gentilli califica como una dramatización de ars gubernandi $i^{114}$, se refleja en el cuadro de Justus Tiel titulado Alegoría de la educación de Felipe III, que representa al príncipe acompañado de la Justicia, que le ofrece su espada, y del Tiempo, que aparta de él a Cupido, símbolo de los placeres vanos.

La obra de Tiel guarda, por su parte, una estrecha relación con la carta de Felipe II de 1585, que contiene instrucciones para la educación de su heredero. En esta se mencionan tres deberes asocidos con el oficio del rey que el príncipe tenía que asumir si quería ser un buen gobernante: promover la obediencia a la ley divina y conservar y poteger la religión católica; convertirse en un monarca prudente, capaz

Treinta Años del lado de la Unión Evangélica. Bajo este disfraz se esconde don Fernando de Austria, rey de Hungría y Bohemia, futuro emperador de Alemania, cuyo enlace con la hermana de Felipe IV en 1629 sirve para consolidar la alianza de las dos ramas de la Casa de Austria. Su identificación en la comedia con la figura del príncipe de Transilvania puede entenderse en términos de la defensa de la hegemonía de la estirpe habsbúrgica en Europa. Ver Piłat Zuzankiewicz, 2014, pp. 378-380 y 388-389.

111. Ver Arellano, 2008, p. 25. Sugiere comparar dicho episodio con el siguiente pasaje de la Política de Dios, p. 50: «No hallarás alguno sin señor en el alma. Donde la lujuria no ha hallado puerta, que se ve raras veces (y fáciles de contar, si no de creer), ha entrado a ser monarca o el descuido, o la venganza, o la pasión, o el interés, o la progalidad, o el divertimiento, o la resignación que de todos los pecados hace partícipe a un príncipe».

112. Este concepto aparece en la empresa XxI Regit et corregit de Diego de Saavedra Fajardo. Ver Bernat y Cull, 1999, p. 350.

113. Esta imagen recuerda el grabado del documento LXXI Firmis haerendum de Andrés Mendo, que representa a un marinero bajando el áncora y el otro averiguando con la sonda el calado. Ver Bernat y Cull, 1999, pp. 560-561.

114. Ver Gentilli, 2013. 
de vencerse a sí mismo; y seguir el ejemplo de Salomón a la hora de impartir justicia a los súbditos ${ }^{115}$. Esta última facultad se menciona en la declaración inicial del rey de la comedia sobre su justo gobierno y, más adelante, se escenifica en la última jornada en que don Fernando, al recibir la noticia de la captura a su flota, manda administrar justicia a su pueblo, castigar los pecados y premiar los servicios, para recuperar el favor del Cielo ${ }^{116}$. Con las primeras dos obligaciones reales el soberano llega a cumplir en consecuencia de la lección sacada de las mencionadas historias amorosas. De esta manera, el monarca, apoyado por su ministro, se transforma en un modelo de príncipe perfecto, de acuerdo con el plan que tenía pensado para Felipe IV el mismo Olivares.

Como hemos podido ver, la comedia quevediana guarda mucha deuda con los dos textos teóricos anteriormente analizados. El autor aprovecha el ideario del Discurso de las privanzas a la hora de presentar el tema central de la pieza, señalado en su título: la conveniencia de la existencia de un único valido y las cualidades morales que este debe poseer. También recurre a dicho escrito para recordar el tópico de la virtud estoica que protege al privado de las adversidades de la fortuna. Los demás motivos que sirven para proyectar la imagen del valido: su condición social desigual a la del monarca y el papel de un simple colaborador, que no le sustituye en el ejercicio de sus facultades ni le separa de los demás súbditos, forman parte tanto de la primera obra seria de don Francisco como de la Política de Dios. Y es de este tratado de donde el autor toma el ideal del príncipe justo y prudente que llega a alcanzar el rey de la comedia gracias a los buenos consejos de su ministro, con lo cual se justifica su posición en la corte.

\section{Conclusiones}

La lectura histórico-política de los textos quevedianos dedicados al tema de la privanza permite adoptar al investigador el punto de vista de sus primeros receptores - cortesanos, estadistas, atentos observadores de la vida política española de la primera mitad del siglo XvII- a los cuales no se les escaparían las alusiones más o menos sutiles a los acontecimientos reales que salpican sus páginas. Su innegable carácter de obras de circunstancia invita a indagar en el trasfondo histórico de su composición -el proceso de institucionalización del cargo del privadoy el momento concreto de su puesta en circulación, determinado por las circunstancias externas -el ambiente de críticas y acusaciones de abuso del poder por parte de los favoritos reales- $\mathrm{y}$ un factor personal -las relaciones del escritor con los validos que sufren una evolución a lo largo

115. Ver Feros, 2002, pp. 56-58.

116. El rey manifiesta su inclinación por la visión providencialista de la historia, abordada por Quevedo en la segunda parte de la Política de Dios, p. 293, según la cual «solo Dios da las victorias, y el pecado los vencimientos y las ruinas». 
de su carrera política. Todos estos elementos tienen un impacto notable en la postura que toma don Francisco ante el nuevo sistema de gobierno.

En el Discurso de las privanzas el joven aspirante a altos cargos en la corte se empeña en legitimar el poder de Lerma y defender su posición debilitada considerablemente tras el escánadolo de la corrupción de sus hechuras, de lo cual se hace eco sinuosamente entre líneas. La Política de Dios, sirviéndose de un velo de ejemplos y pasajes bíblicos, testimonia la transición entre el gobierno de un solo favorito, encarnado por Lerma, y la privanza colegiada, compartida por Olivares y Baltasar de Zúñiga, cuyos buenos efectos el autor no deja de exaltar en los Grandes anales redactados por las mismas fechas. No es de olvidar que Quevedo escribe ambas obras desterrado en la Torre de Juan Abad con vistas a poder volver a la corte. En cambio, una vez integrado en el círculo proolivarista, en la comedia Cómo ha de ser el privado vuelve a justificar el valimiento ejercido por el conde-duque, tras la muerte de su tío, que implica un disfrute exclusivo de la amistad regia y del poder.

Los cambios de la visión quevediana del sistema administrativo español guardan una innegable deuda con los principales tratados políticos de la época que, por una parte, se inscriben en el marco de la campaña de legitimación del poder del privado y, por otra, abogan por su limitación a fin de restaurar la autoridad del monarca. En las obras que defienden la posición privilegiada de Lerma y Olivares, Discurso de las privanzas y Cómo ha de ser el privado respectivamente, el autor se ciñe a la línea argumentativa del discurso elaborado a principios del siglo por fray Pedro Maldonado, que proporciona una definición del oficio del privado, expone los requisitos imprescindibles para desempeñar dicha función y justifica, desde la perspectiva de la práctica burocrática, la conveniencia de la existencia de un privado. Mientras que en la Política de Dios el escritor examina el régimen de privanza desde el punto de vista de la experiencia del gobierno del valido de Felipe III y apunta a las reformas que se precisa introducir para evitar otros casos de corrupción y clientelismo. En esta tarea se inspira en los postulados de fray Juan de Santamaría del retorno al sistema de gobierno ejercido por el Rey Prudente, cuyo partidario se muestra el mismo conde-duque.

A pesar de diferentes soluciones al dilema si el rey debe tener uno o más validos que Quevedo ofrece en determinados momentos históricos, la visión de la privanza que se desprende de sus obras es bastante coherente y se funda en tres pilares: la relación del valido con el monarca, marcada por una inclinación pero también una dependencia del uno con respecto al otro, que excluye igualdad entre ellos; el alto ideal moral, basado en la ética estoica y cristiana, que ha de encarnar el favorito; y su función de ministro consejero que no usurpa el poder que no le corresponde ni tiende a aislar a su señor de todo el mundo, sino que le sirve de guía en lo moral y lo político. La actitud del autor hacia el apartamiento de los malos privados y su insistencia en imponerles castigos que merecen son evidentes huellas de los altibajos en sus relaciones con 
Lerma y Olivares. No obstante, incluso la decepción de la política de sus respectivos gobiernos no le hace a nuestro escritor despreciar las principales ventajas que conlleva el sistema de valimiento: el fortalecimiento del poder real y la posible recuperación de la grandeza de España.

\section{BibLiografía}

Aranguren, José Luis, «Lectura política de Quevedo», Revista de Estudios Políticos, XXIX, 1950, pp. 157-167.

Arellano, Ignacio, «El poder político y sus límites en la obra de Quevedo», $L a$ Perinola, 12, 2008, pp. 17-33.

Arellano, Ignacio, "Cómo ha de ser el privado y el modelo de privanza en Quevedom, en L'Espagne des validos (1598-1645), ed. Rudy Chaulet, Paris, Ellipses, 2009, pp. 203-220.

Arellano, Ignacio, «Introducción» a Francisco de Quevedo, Teatro completo, ed. Ignacio Arellano, Celsa Carmen García Valdés, Madrid, Castalia, 2011, pp. 21-56.

Arredondo, María Soledad, «La comedia como fuente de información: el rey, el valido y las mujeres de palacio en Cómo ha de ser el privadom, en Miscelánea teatral áurea, dir. José María Díez Borque, Madrid, Visor, 2015, pp. 11-25.

Benigno, Francesco, La sombra del rey: validos y lucha política en la España del siglo XVII, Madrid, Alianza, 1994.

Bernat Vistarini, Antonio y John T. Cull, ed., Enciclopedia de emblemas españoles ilustrados, Madrid, Akal, 1999.

Clamurro, William H., "The Rhetorical Politics of the Política de Dios», en Language and Ideology in the Prose of Quevedo, Newark, Delaware, Juan de la Cuesta, 1991, pp. 120-153.

De Armas, Frederick A., “"En dos pechos repartidos": Felipe IV y su valido en Cómo ha de ser el privadom, Hispanófila, 47, 2004, pp. 9-20.

De Armas, Frederick A., «Vientos contrarios: tempestades de pasión y poder en Cómo ha de ser el privadom, La Perinola, 17, 2013, pp. 109-117.

Díaz Martínez, Eva María, «Estudio preliminar» a Francisco de Quevedo, Discurso de las privanzas, ed. Eva María Díaz Martínez, Pamplona, Eunsa, 2000, pp. 19-142.

Durand, José, “Andanzas del padre Maldonado y su privado ejemplar», Nueva Revista de Filología Hispánica, xxIx, 1980, pp. 312-342.

Elliott, John H., "Quevedo and the Count-Duke of Olivares», en Quevedo in perspective, ed. James Iffland, Newark, Juan de la Cuesta, 1982, pp. 227-250.

Elliott, John H., El conde-duque de Olivares: el político en una época de decadencia, Barcelona, Crítica, 1990.

Elliott, John H., «Unas reflexiones acerca de la privanza española en el contexto europeo", Anuario de historia del derecho español, 67, 1997, pp. 885-899.

Elliott, John H., «Conservar el poder: el conde-duque de Olivares», en Elmundo de los validos, ed. John H. Elliott y Laurence Brockliss, Madrid, Taurus, 2000, pp. 165-180.

Elliott, John H., «El conde-duque de Olivares y la herencia de Felipe II», en España en Europa: estudios de historia comparada, Valencia, Universidad de Valencia, 2002, pp. 143-163.

Elliot, John H. y José Francisco de la Peña y Fernando Negredo, Memoriales y cartas del conde duque de Olivares, Madrid, Alfaguara, 1979-1981, 2 vols. 
Enciso Recio, Luis Miguel, «La Corte de dos mundos», en Felipe IV: el hombre y el reinado, ed. José Alcalá-Zamora, Real Academia de la Historia, Centro de Estudios Europa Hispánica, 2005, pp. 67-136.

Escudero López, José Antonio, «Privados, validos y primeros ministros en al monarquía española del antiguo régimen (viejas y nuevas reflexiones)», Revista Chilena de Historia del Derecho, 22, 2010, pp. 322-331.

Ettinghausen, Henry, «Ideología intergenérica: la obra circunstancial de Quevedo", en Quevedo y la crítica a finales del siglo XX, ed. Victoriano Roncero, J. Enrique Duarte, Pamplona, Eunsa, 2003, vol. 2, pp. 27-64.

Fernández Mosquera, Santiago, "Quevedo y el valimiento: del Discurso de las privanzas hasta Cómo ha de ser el privadon, Bulletin of Spanish Studies, 90, 4-5, 2013, pp. 552-576.

Feros, Antonio, «Imágenes de maldad, imágenes de reyes: visiones del favorito real y el primer ministro en la literatura política de la Europa moderna, c. 1580-1650», en El mundo de los validos, ed. John H. Elliott y Laurence Brockliss, Madrid, Taurus, 2000, pp. 293-320.

Feros, Antonio, El Duque de Lerma: realeza y privanza en la España de Felipe III, Madrid, Marcial Pons, 2002.

Ferrer Valls, Teresa, «El juego del poder: Lope de Vega y los dramas de la privanza», Modelos de vida en la España del Siglo de Oro: el noble y el trabajador, eds. Ignacio Arellano y Marc Vitse, 2004, pp. 159-185.

Gentilli, Luciana, «La dramatización de un ars gubernandi: Cómo ha de ser el privado de Francisco de Quevedo", La Perinola, 17, 2013, pp. 121-136.

Guevara, Antonio de, Libro llamado Aviso de privados y doctrina de cortesanos, Pamplona, Thomas Porralis, 1579.

Hernández Araico, Susana, «Teatralización de estatismo: poder y pasión en Cómo ha de ser el privado de Quevedo", Hispania, 82, september 1999, pp. 461-471.

Iglesias, Rafael, «El imposible equilibrio entre el encomio cortesano y la reprimenda política: hacia una nueva interpretación de Cómo ha de ser el privadom, La Perinola, 9, 2005, pp. 267-298.

Iglesias, Rafael, “Francisco de Quevedo como practicante de la disimulación defensiva en Cómo ha de ser el privado y El chitón de las tarabillas,, La Perinola, 17, 2013, pp. 69-106.

Jaramillo Cervilla, Manuel, Personalidad y pensamiento político de Quevedo, Granada, Excelentísima Diputación Provincial de Granada, 1981.

Jauralde, Pablo, Francisco de Quevedo (1580-1645), Madrid, Castalia, 1998.

Linde, Luis María, Don Pedro Girón, Duque de Osuna: la hegemonía española en Europa a comienzos del siglo XVII, Madrid, Ediciones Encuentro, 2005.

Lipsius, Justo, Los seis libros de las políticas, Madrid, Imprenta Real, 1604.

Maldonado, fray Pedro, Discurso del perfecto privado, 1609. (Biblioteca Nacional de España, Mss. 6778) http://bdh-rd.bne.es/viewer.vm?id=0000135746\&pa ge $=1 \&$ bt=europeanaapi (consulta 15-01-2016)

Monjarret, Elise, “Quevedo, ¿un panfletario en la corte? Los "consejos" al privado o las estrategias de mostración / denunciación del impostor en el Discurso de las privanzasm, en Opinión pública y espacio urbano en la Edad Moderna, dir. Antonio Castillo Gómez y James S. Amelang, Gijón, Ediciones Trea, 2010, pp. 441-453.

Peraita, Carmen, «En torno a la circunstancia histórica de la Política de Dios I de Quevedo: "... auiendo de tener lado"», Studia Aurea. Actas del tercer Congreso de la Asociación Internacional Siglo de Oro, ed. Ignacio Arellano, Frédéric Serralta, Marc Vitse, Pamplona, Griso / Lemso, 1996, vol. 3, pp. 389-398. 
Peraita, Carmen, Quevedo y el joven Felipe IV: el príncipe cristiano y el arte del consejo, Kassel, Edition Reichenberger, 1997.

Piłat Zuzankiewicz, Marta, «Hacia una lectura política de Cómo ha de ser el privado de Francisco de Quevedom, La Perinola, 18, 2014, pp. 369-393.

Roncero, Victoriano, Los Grandes anales de quince días de Quevedo. Edición y estudio, Madrid, Universidad Complutense de Madrid, 1988.

Roncero, Victoriano, “Los límites del poder en Quevedo: la figura del valido", Autoridad y poder en el Siglo de Oro, ed. Ignacio Arellano, Christoph Strosetzki, Edwin Williamson, Madrid / Frankfurt, Universidad de Navarra / Iberoamericana / Vervuert, 2009, pp. 137-158.

Roncero, Victoriano, "Quevedo y el Duque de Lerma (1605-1615)», La autoridad política y el poder de las letras en el Siglo de Oro, ed. Jesús María Usunáriz y Edwin Williamson, Madrid / Frankfurt, Universidad de Navarra / Iberoamericana / Vervuert, 2013, pp. 73-89.

Rubio, Fernando, «El Discurso de las privanzas de Quevedo y el Tratado del perfecto privado del P. Pedro Maldonado, o.s.A.», Anuario Jurídico Escurialense, v, 1964, pp. 575-585.

Quevedo, Francisco de, Obra poética: teatro y traducciones poéticas, ed. José Manuel Blecua, Madrid, Castalia, 1981, vol. Iv.

Quevedo, Francisco de, Política de Dios, Gobierno de Cristo, ed. James O. Crosby, Madrid, Castalia, 1966.

Quevedo, Francisco de, Discurso de las privanzas, ed. Eva María Díaz Martínez, Pamplona, Eunsa, 2000.

Quevedo, Francisco de, Grandes anales de quince días, ed. Victoriano Roncero, en Obras completas en prosa, dir Alfonso Rey, Madrid, Castalia, 2005, vol. III, pp. 43-115.

Quevedo, Francisco de, Cómo ha de ser el privado, en Teatro completo, ed. Ignacio Arellano y Celsa Carmen García Valdés, Madrid, Castalia, 2011, pp. 125-242.

Sánchez Sánchez, Ángel, La imagen del Rey don Pedro en la literatura del Renacimiento y del Barroco, Guadalajara, Editorial Aache, 2011.

Santamaría, Juan de, Tratado de república y política christiana, Valencia, Pedro Patricio Mey, 1619.

Suárez Fernández, Luis y José Andrés Gallego, Historia General de España y América, vol. VIII. La crisis de la hegemonía española, siglo XVII, Madrid, Ediciones Rialp, 1986.

Tomás y Valiente, Francisco, Los validos en la monarquía del siglo XVII: estudio institucional, Madrid, Siglo xxI, 1982.

Urrutia Gómez, Jorge, “Quevedo en el teatro político», en Homenaje a Quevedo. Actas de la II Academia Literaria Renacentista. Universidad de Salamanca, 10, 11 y 12 de diciembre, 1980, ed. Víctor García de la Concha, Salamanca, Universidad de Salamanca, 1982, pp. 171-185.

Voinier, Sarah, «De la théorie à la fiction: le regard de Quevedo sur le favori idéal», en Comprendre "Cómo ha de ser el privado»: actes de la journée d'étude du 18 décembre 2009, dir. Morgane Kappé-Le Moing, Rafaèle Audoubert, Gilles Del Vecchio, Saint-Étienne, Publications de’l Université de Saint-Étienne, 2010, pp. 107-121. 



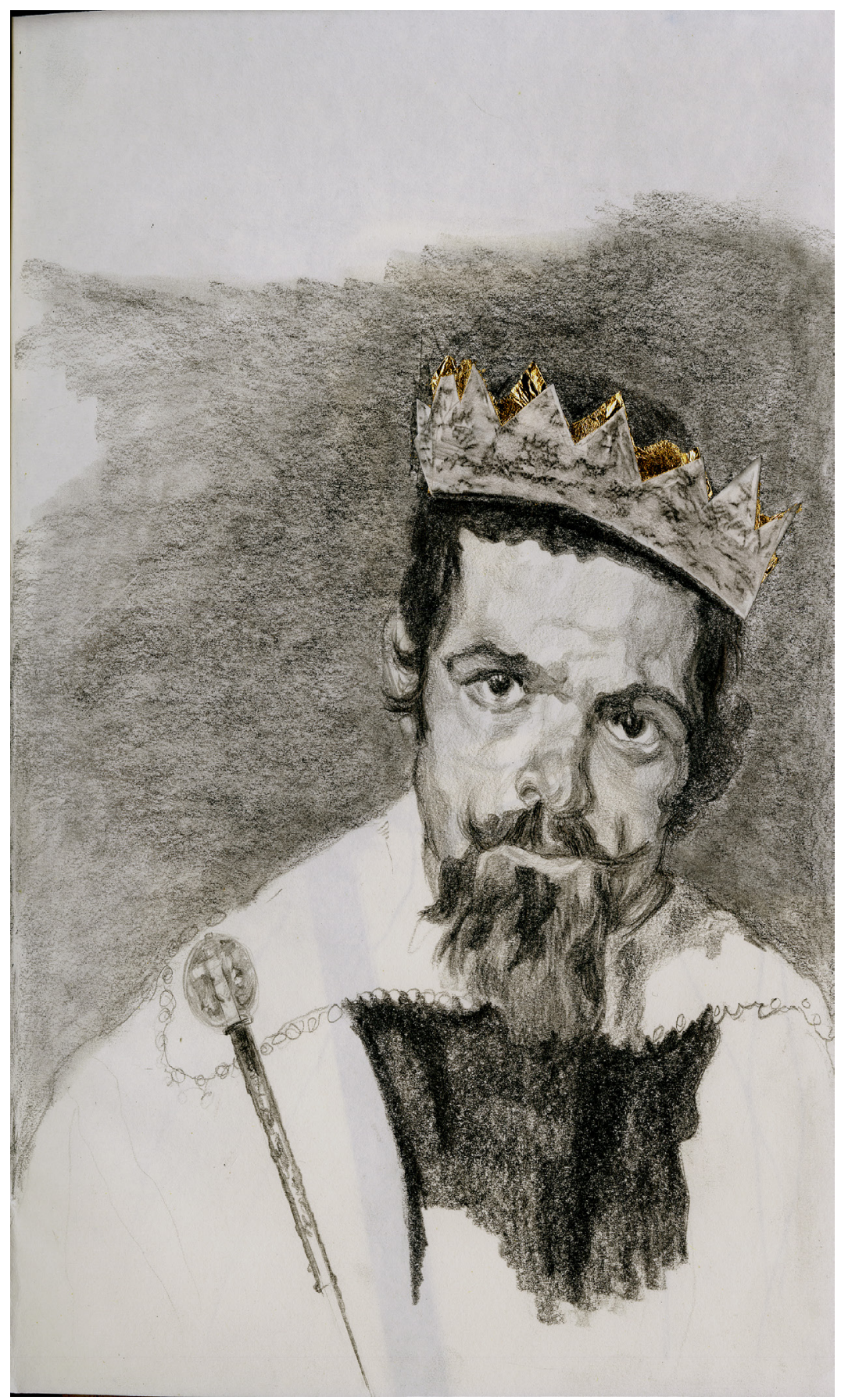


